\title{
Dependency with Chinese Characteristics? A case study of Chinese engagement in Chile
}

Daniel Liebetreu*

\begin{abstract}
This article demonstrates that while Chile has generally been successful in capturing the benefits of China's economic rise, the country is also developing a market dependency on China in certain export sectors, namely copper and cherries. In order for Chile to break its increasing dependency on China, it must diversify its export markets and foster a more balanced conversation about Chinese engagement. In addition, Chile must invest more on value-added production prior to export. Chinese trade and investment are critical to a quick economic recovery from the pandemic; however, policies must be implemented now to ensure Chile maximizes the potential benefits and minimizes the inherent risks in the long term.
\end{abstract}

Key words: China - market dependency - Chilean mining - Chilean agriculture - foreign direct investment

\section{¿Dependencia con características chinas? Un estudio de caso de la inversión china en Chile}

\section{Resumen}

Este artículo demuestra que, si bien Chile en general ha tenido éxito en capturar los beneficios del ascenso económico de China, el país también está desarrollando una dependencia del mercado chino en ciertos sectores de exportación, por ejemplo, el cobre y las cerezas. Para que Chile pueda romper su creciente dependencia de China, debe diversificar sus mercados de exportación y fomentar una conversación más equilibrada sobre el compromiso chino. Además, Chile debe invertir más en producción de valor agregado antes de exportar. El comercio y la inversión chinos son fundamentales para una rápida recuperación económica después de la pandemia; sin embargo, se deben implementar políticas para asegurar que Chile maximice los beneficios potenciales y minimice los riesgos inherentes a lo largo plazo.

Palabras clave: China - dependencia del mercado - minería chilena - agricultura chilena - inversión extranjera directa

\footnotetext{
* Magister en Relaciones Internacionales, Pontificia Universidad Católica de Valparaíso (PUCV, Chile). Becario de la Fundación Olmsted y oficial militar estadounidense. Las opiniones expresadas son las del autor y no reflejan la posición oficial del gobierno de Estados Unidos. Correo electrónico: daniel.liebetreu@gmail.com
} 


\section{Introduction}

The explosive economic growth of the People's Republic of China (PRC) has fundamentally changed the balance of the global economy. While this growth has contributed to progress in much of the developing world, especially across the global south, the outcomes have varied significantly depending on trade and industrialization strategy, institutional strength, and domestic policy. In Latin America and the Caribbean (LAC), policy makers are debating how to engage the rising giant in East Asia while also creating the conditions for self-sustaining economic growth. The traditional powers in the United States and Europe warn of a revisionist regime that does not play by the rules and largely operates for its own financial and geopolitical gain, but many LAC economists and business leaders are intrigued by the availability of credit, the huge market for exports, the low cost manufactured goods, and the expanding source of foreign direct investment (FDI).

In many ways, the economic connection that China has with LAC is natural and mutually beneficial. China's construction boom and growing middle class have increased global demand for energy, building materials, and commodity foods. During the boom years from 2003 to 2013, the result for commodities exporters in Latin America was higher prices, excellent growth rates, and increased revenues. However, when the PRC began its shift in economic policy to internal consumption in 2014, commodity prices began to fall and much of the region fell into a recession. Much of the growth during the boom was the result of "reprimitization" that left exporting countries exposed as price takers on the international market. The depth of the recession or economic slowdown in each country was determined by the policies implemented during the boom years. Some countries fared far worse than others.

In this context, the distinguished economist and scholar Barbara Stallings published a Cambridge Research Element in early 2020 questioning whether China's economic rise is creating dependent relationships in LAC that could stifle sustainable economic growth. In Dependency in the Twenty-First Century? The Political Economy of China-Latin America Relations, Stallings presents a compelling case that China's actions are creating a new dependent relationship with China at the center and much of Latin America in the periphery and semi-periphery. Due to the short length of the publication -just seventy pages- her analysis is only conducted at the regional level. As a result, she calls on scholars to expand on her research using case studies at the national level and below. This article seeks to answer that call by examining the PRC's engagement in Chile.

Recognizing the polarizing effect that dependency theory has had in Latin America, the goal of this article is not to debate the viability of dependency as a theoretical framework, but rather to use the model laid out by Dr. Stallings to examine the impact of Chinese economic and political engagement in Chile. In that light, this article will utilize the three dependent mechanisms -markets, leverage, and linkage- which Stallings (1992) described in an earlier essay criticizing the United States involvement in Latin America during the 1980s and 1990s (pp. 48-58). According to that essay, markets are the economic context nations operate in, specifically the globalized export markets and available external financing. Leverage is the force developed nations apply on dependent states in order to alter their behavior. And finally, linkage constitutes the relationships with which dependent nations come to define their interests in a similar way to more powerful actors, whether through education, soft power influence, employment, or ideas. In the context of Latin America and China, Stallings hypothesizes that the dependent relationship is most strong through the mechanisms of markets and linkage. As this article will demonstrate, this is certainly true in the case of Chile.

Sino-Chilean relations are interesting and, in many ways, exceptional because the Chileans managed to reap widespread benefits during the Chinese led commodities boom (20032013) and maintained positive, albeit more modest, growth in the period that immediately followed. The small, free-market Chilean economy is one of three LAC economies that embraced 
China following its acceptance into the World Trade Organization (WTO) by signing a bilateral Free Trade Agreement (FTA) ${ }^{1}$. This approach was highly effective at increasing bilateral trade, especially for the export of copper and agricultural products. Now as Chinese financing and investment to the LAC region has slowed ${ }^{2}$, Chile has become a primary destination for Chinese FDI, especially in the energy and services sectors.

What did Chile do to reform its economy during the 1990s that allowed it to take advantage of the commodity boom period? How did it use a bilateral free trade agreement to acquire more favorable trade conditions than the rest of the region? And how have we seen Chinese policy and behavior toward Chile shift during the Xi Jinping years? This article seeks to answer these questions and more by analyzing Chile's historical positions toward the PRC, its economic reforms and embrace of globalization, and the impact the Chinese have had on specific Chilean industries. Since the 1970s, the small, coastal nation has maintained a pragmatic foreign policy toward China while establishing itself as a champion of free trade. The combination of these two strategies helped the Chileans achieve the first ever bilateral FTA with the PRC. By engaging with the Chinese during the 1990s and maintaining a constant policy position toward the Asian giant through multiple political regimes, Chile has demonstrated the potential agency that LAC countries have in these negotiations. This direct engagement is responsible for the success the Chileans have had in bilateral affairs and should be viewed as a potential model for other countries in the region.

However, the Chilean story is certainly not devoid of drawbacks and missteps. The sheer size of the Chinese market and nature of the Chinese Communist Party (CCP) and its state-owned enterprises (SOE) render this an impossible expectation. As this article will explain, specific elements of the Chilean economy have become dependent on Chinese markets to maintain growth. For example, China imports more than $95 \%$ of Chile's lucrative cherry harvest and almost half of all Chilean copper and slag exports. Furthermore, the bilateral relationship was tested when a Chinese SOE had a deal to buy a copper mine canceled by the Chilean congress in 2008, and now, in the midst of the coronavirus pandemic, the congress is debating whether to allow a Chinese SOE to purchase a majority stake in the Chilean electrical grid. While Sino-Chilean relations have maintained a generally positive tone and there is no question that bilateral trade up to this point has been mutually beneficial, the Chileans would be wise to diversify their export destinations and consider controls to manage FDI by foreign SOEs in certain strategic sectors.

\section{A History of Sino-Chilean Relations}

For more than half a century, Sino-Chilean relations have been marked by pragmatic foreign policies centered around non-intervention and regional leadership with respect to economic policy. Prior to the administration of Salvador Allende (1970-1973), Chilean presidents had been unwilling to break ties with the Republic of China (Taiwan) due to ideological similarities and Cold War politics. Despite the lack of diplomatic relations, both Allende and the famous leftist poet and diplomat Pablo Neruda visited mainland China during the 1950s and were well connected with the founding members of the CCP. Therefore, it should come as no surprise that the recognition of the PRC was a high priority for Salvador Allende when he was sworn in as president on November $3^{\text {rd }}, 1970$. In only the second major foreign policy decision of his

\footnotetext{
${ }^{1}$ In her book Dragonomics: How Latin America Is Maximizing (or Missing Out on) China's International Development Strategy, Carol Wise (2020, pp. 130-152) analyzes the successes of the three LAC countries that have signed bilateral FTAs with the Chinese: Chile, Costa Rica, and Peru. Wise stresses the importance of the Chile-China FTA as the example used by the Peruvians and Costa Ricans.

${ }^{2}$ For the first time since 2006, China did not offer any financing to Latin American governments or SOEs in 2020. For more on Chinese finance trends in the region, see Margaret Myers \& Rebecca Ray (2021). Shifting Gears: Chinese Finance in LAC, 2020. Washington DC: Inter-American Dialogue
} 
administration -the reestablishment of relations with Fidel Castro's Cuba was the first- Allende formally established relations with the PRC on December $15^{\text {th }}, 1970$. This made Chile the first South American country to establish diplomatic relations with the PRC, an act that is still often cited by diplomats on both sides. It also put Chile in a unique position in that it had diplomatic relations with the PRC when it joined the United Nations (UN) in $1971^{3}$. Furthermore, the Chileans scored another first when their treasured Esmeralda became the first warship to port in mainland China when it arrived in Shanghai in 1972. Although this was hardly a display of hard power since Esmeralda is a 19th century style frigate used for training and publicity (Ellis, 2011).

Unfortunately for Allende's regime, publicity stunts did not lead to financial support. The Chinese were in the throes of the Cultural Revolution and supporting Communist movements closer to home. The CCP was in no position to help the Chileans in their quest to become the first successful Socialist state in South America. In fact, in a rather remarkable letter sent from Zhou Enlai to Salvador Allende in February of 1973, the PRC premier apologized for not being able to help more, and then urged Allende to make gradual, sustainable changes. Zhou writes:

We would have liked to make a relatively large contribution to the economic construction in which the Chilean people are committed. But, as our economic power is still very limited, and in addition, we are obligated to help the people of Vietnam and all of Indochina in their struggle, we find ourselves in a situation where our strength does not match our will. (...) In order to develop an independent national economy, Third World countries have to work long and hard, pay a certain price, and make certain sacrifices. We trust that our peoples are all brave and industrious [but] it is only by acting in accordance with actual conditions and realistic possibilities and in a prepared and gradual manner that one can advance step by step toward economic change and improved living conditions for the people (Fermandois, 2005, p. 387).

Unfortunately, one could argue that Allende's government had not been making changes in a "gradual manner" or advancing "step by step", and the political blow back was fierce. Despite succeeding in nationalizing Chilean copper -an important piece of Chile's ongoing development strategy that will be discussed later- inflation skyrocketed, and the economy fell into a recession. Just over seven months after this letter was written, the first ever democratically elected socialist would take his own life during a military coup, cementing his legacy on the left as a martyr for the socialist cause and on the right as a symbol of its failures.

Despite the hard ideological shift under Pinochet's military government, pragmatism prevailed over ideology in Sino-Chilean relations. The PRC was one of only two communist countries that did not withdraw its embassy in Santiago following the coup ${ }^{4}$. The Chinese had no intention of severing relations with one of the few countries that had shown a willingness to back Beijing's "one China” policy (Montalva \& Navia, 2006). As a result, the two governments found in each other a rare friend in an international system that did not support their type of government. However, the two governments shared common ground based the principle of non-intervention and were vehemently against the Soviet Union (although for very different reasons). This antiSoviet fervor increased even further in the late-1970s as both countries began their free-market reforms (Errázuriz Guilisasti, 2006, pp. 171-173). Ultimately, the most significant cooperation between Pinochet's government and the PRC involved Antarctica when the PRC supported the

\footnotetext{
${ }^{3}$ Coincidentally, due to the alphabetization of seats in the UN, Chile and China sit next to each other in the General Assembly Hall. This is a fact that several Chilean diplomats have mentioned is a great benefit to their country since many Chinese diplomats in the UN reference an uncommon bond with their Chilean "neighbors" (Méndez Morán, 2018, p. 327).

${ }^{4}$ The other Communist government that maintained an embassy in Santiago after September $11^{\text {th }}, 1973$ was the Romanian Socialist Republic.
} 
Chilean claim of sovereignty over a large portion of the continent, and in turn, Chile allowed the Chinese to build their Antarctic Great Wall Base within those territorial claims.

As the Cold War drew to a close, the Soviet policies of Glasnost and Perestroika created conditions for reforms in the USSR and expectations of reform in other countries around the world. There were hopes of democratic reforms in both Chile and the PRC, but the military government in Chile and the CCP chose divergent paths. By the time the Berlin Wall fell on November 9th, 1989, the Chileans had held a plebiscite and voted for a return to democracy. The first presidential elections since the election of Salvador Allende took place on December $14^{\text {th }}$, 1989, and Patricio Aylwin was inaugurated on March $11^{\text {th }}$, 1990. Meanwhile, the Chinese chose to meet pro-democracy demonstrations with violence following the peaceful occupation of Tiananmen Square from April $15^{\text {th }}$ to June $4^{\text {th }}$, 1989. In the period of just 18 months, Chile had peacefully transitioned from a military dictatorship to a multi-party democracy, while the PRC's violent response in Tiananmen led to its worst foreign relations episode in its history.

Despite the political divergence, both countries entered the 1990s committed to economic reforms and poverty reduction. China adopted an export-led model focused on light manufacturing while Chile maintained its focus on mineral exports and the expansion of agricultural, fish, and forest products exportation. The Chileans continued to uphold the principles of the free market and sought lower tariffs and free trade agreements with its main trading partners. As China began its bid for admission into the WTO, Chile established itself as a global champion of free trade. In this context, the two countries would begin the process of economic integration that characterizes their relationship today.

\section{The Chile-China FTA}

There is no clearer example of Chile's embrace of free trade and commitment to globalization than their FTA with the PRC. Furthermore, the strategic vision the Chileans demonstrated across multiple presidential administrations is nothing short of remarkable. Just five years after the return of democracy in Chile, then-president Eduardo Frei traveled to Beijing to meet with his counterpart Jiang Zemin. It was 1995 and the PRC was just the eighth largest economy in the world and still recovering from the diplomatic fallout of their Tiananmen Square crackdown. Instead of focusing on the uncertainties surrounding the Chinese market, the Chileans saw an opportunity. President Frei proposed the idea that Chile and China begin negotiations toward a bilateral FTA (Méndez Morán, 2018, pp. 322-323).

There is no doubt that proposing an FTA in 1995 would have surprised the Chinese, after all, the Chinese were still years away from signing their first FTA with the ASEAN bloc in 2002. But like the Chileans, the Chinese are very pragmatic. While the Chileans saw an opportunity to build an economic partnership on their terms, the Chinese saw a chance to learn from one of the early champions of free trade. From the Chinese perspective, an FTA would solidify ties with the world's largest copper exporter at a time when Chinese demand for construction materials was exploding. In addition, the risks to Chinese manufacturing were minimal -the Chilean manufacturing sector was much smaller than that of other LAC countries due to the deindustrialization during the Pinochet regime's free market reforms. But the Chinese were not quite ready to start negotiations (Méndez Morán, 2018, p. 323).

In the decade following Eduardo Frei's visit to China, the Chileans continued their pursuit of an FTA in the hopes that domestic producers would export more value-added goods to China, and, in turn, the Chinese would invest in non-resource extraction sectors of the Chilean economy (Wise, 2017, p. 157). The Chileans extended their first olive branch in 1999, formally becoming the first Latin American country to support China's entry into the WTO. Meanwhile, the Chileans were building a global reputation for their highly professional trade negotiations with developed countries, to include five high profile FTAs: with Canada in 1997, Mexico in 1999, the European 
Union in 2003, and the United States and South Korea in 2004. Despite two in person meetings, Frei's successor Ricardo Lagos did not make progress with Jiang Zemin. The Chinese may have been reluctant to begin negotiations until the Chilean's FTA with the United States entered into force on January $1^{\text {st }}, 2004$. At that point in the early 2000 s, the Chinese were still following Deng's old adage and "biding their time" in the Western Hemisphere. Then in 2004, following the ascension of Hu Jintao, things began to progress. Hu created a committee to study a possible Chile-China FTA. Then, the Chinese asked that the Chileans recognize them as a market economy, a prerequisite to begin negotiations (Vallina-Hernandez, 2021). Finally, when Hu met with Lagos in November 2004 at the APEC leaders conference in Santiago, the Chinese announced that they would begin negotiations on a bilateral FTA. It had taken nearly a decade, but the Chilean's persistence was finally paying off.

So why were the Chileans so persistent in their quest to sign an FTA with the Chinese? China's growing market offered opportunity to Chilean exporters of copper, lithium, molybdenum, wood and wooden furniture, forest products, salmon and other fish, wine, and fresh produce. For this reason, Chile's export promotion agency ProChile named China its number one priority market, especially for agricultural products (González, 2018, p. 11). But formalizing a trade deal with the Chinese aligned with a more broad, macroeconomic priority. As a small player on the global stage, Chile depends on standards of behavior and international rules to maintain its interests. None of those standards are more important than what Chilean scholar Manfred Wilhelmy (2017) describes as a "high degree of fluidity of international trade" (p. 170). He writes that these interests are generally preserved through "international stability and preservation of peace, a commitment to non-intervention, the observance of validly concluded treaties, and the peaceful settlement of disputes" (p. 170). Essentially, Chile does not have the hard power to ensure other nations follow the rules and norms of the international system, so they have been championing an interdependent global system of commerce to align other nations interests with their own. An FTA with the PRC further promoted this vision.

While Chile's interests seem straight forward, a more interesting question is: why did the Chinese choose a small South American nation for its first ever bilateral FTA? Certainly, Chile's main exports of copper, lithium, and food products aligns with China's globalized development strategy. But there were two larger factors in play that led the Chinese to negotiate with Chile. First of all, the Chinese needed to develop experience in trade negotiations and Chile offered a low risk, high reward opportunity. The FTA was low risk in the sense that the Chilean market was not critical to the Chinese development strategy in the event that negotiations went poorly. And the deal was high reward since the Chinese needed more experience in bilateral trade negotiations and the Chileans were happy to oblige (Méndez Morán, 2018, p. 323). A second element that made an FTA with Chile appealing was that it served as a door to the rest of the liberalized economies in South America. Restrictions imposed by Mercosur kept the Brazilians and Argentines from negotiating a bilateral deal with the PRC, and similarly NAFTA restricted the Mexicans, but the Chileans had no such commitments. Once the Chile-China FTA was signed, the Chinese had a base draft for additional agreements in LAC (Peru and Costa Rica) and around the world (Australia, New Zealand, Pakistan, South Korea and several others.) So, while the Chileans got access to a massive and rapidly growing economy, China got a lesson on how to access the rest of the world (Heine, 2006, pp. 143-144).

When negotiations began in January of 2005, many economists were skeptical that Chile could get a fair deal due to the imbalance in market size, but the Chilean negotiators had leverage on two fronts: China needed to gain experience in bilateral negotiations and wanted cheaper access to Chilean copper. So, when China declined the Chilean's initial proposal to not include a list of exclusions, the opportunity arose for Chile to protect elements of their domestic industry from Chinese competition. In an interview with the author, former negotiator for the Chilean Ministry of Commerce Ana María Vallina-Hernández (2021) recalled that there was excellent public-private communication as companies and trade unions were often consulted throughout 
the negotiations. As a result, Chile was able to protect products like clothing and footwear. As Carol Wise (2017) observes:

Whereas most other Western Hemisphere FTAs have strong provisions for increased market access in manufacturing sectors, Chilean negotiators were able to completely exclude 152 "sensitive products" from this FTA while obtaining immediate duty-free access to the Chinese market for 92 percent of Chile's products covered by the agreement (p. 157).

It was the height of the construction boom in China, therefore Chinese negotiators accepted barriers to access Chilean consumer markets in exchange for access to Chilean copper exports. In addition, the initial FTA only included the reduction of tariffs on goods. There would be two subsequent rounds of negotiations to add sections on services (signed in April 2008) and investments (signed in September 2012). In addition, the two countries expanded their FTA in November 2017 to include $98 \%$ of goods exported by both countries while expanding or adding sections on rules of origin, environmental protection, telecommunications, e-commerce, and fair competition (PRC Ministry of Commerce, 2019). These moves demonstrate a commitment to the new trade agenda sought by the WTO during the failed Doha Round and signify an expansion of trade liberalization by both parties. However, there is still a significant imbalance between the relatively small barriers to enter Chile in the realm of services and FDI and the numerous barriers insisted on by the PRC to enter their market. This imbalance remains a major reason why China has not achieved the highly sought-after "market economy status" within the WTO (Wise, 2020, pp. 141, 145-146).

The impact this FTA has had on bilateral trade has been nothing short of remarkable. In 2006, the year the FTA was signed, bilateral trade was just under US\$ 8.1 billion annually. China was providing $9.6 \%$ of Chilean imports and buying up $11.7 \%$ of Chilean exports. By 2018 , total bilateral trade had increased by a factor of five, to US $\$ 42.8$ billion. Meanwhile, China has passed the United States as Chile's largest trade partner and now accounts for $23.6 \%$ of imports and an astounding $33.5 \%$ of exports. As the Chilean negotiators and strategists hoped, this increase has impacted more than just copper exports and is benefitting more labor-intensive industries like agriculture and salmon farming. The explosion of commerce helped Chile recover quickly from the global financial crisis in 2009 (annual GDP growth from 2010-2013 was 5.33\%) and maintain the highest levels of gross fixed capital formation (GFCF) in the region both during and after the China boom. Meanwhile, from the Chinese perspective, the FTA served its purpose. Since 2006, $85 \%$ of Chilean exports have been copper and other ores to feed China's construction boom and industrialization, or what Carol Wise (2020) describes as "China's internationalized development strategy" (p. 132). In addition, the updated FTA and increased diplomatic and commercial ties are finally attracting more Chinese FDI outside the mining sector. As we shall see later in this article, Chinese SOEs and private firms are investing in energy infrastructure, transportation, digital communications, and agriculture, including in the wine industry.

The success the Chileans have had with their free trade agenda has also created conditions for excellent diplomatic relations. In bilateral meetings between heads-of-state, diplomats, and trade representatives, both sides often mention the extensive series of "firsts" that define the relationship. As mentioned in the previous section, the Chileans were the first country in South America to recognize the PRC in 1970. In addition, Chile was the first in LAC to support China's entry into the WTO in 1999 and recognize China as a market economy in 2004. Finally, Chile was the first nation to sign a bilateral FTA in 2005 and to upgrade its FTA in 2017. Most recently, Chile is the only country in LAC to send their president to both Belt and Road Initiative forums: President Bachelet in 2017 and President Piñera in 2019 (Reyes Matta, 2020). The relationship continues to be pragmatic and constructive, what journalist Daniel Méndez-Morán (2018) describes as "Realpolitik in its purest form" (p. 327). Both sides prefer to avoid political discussions that can hinder commerce. Moreover, they strive to promote a foreign policy based 
on "mutual respect, non-intervention, territorial integrity, equality and cooperation" (Errázuriz Guilisasti, 2006, p. 171).

But relations have grown more complicated in recent years as Chinese interests become more visible to the general public. For example, one of the main missions of the Chilean Navy has become the tracking of a several hundred vessel fleet of Chinese fishing vessels as it skirts the Chilean exclusive economic zone (EEZ) every year from September to December. As Evan Ellis (2020) writes, Chinese fishing vessels constitute 18 of the 22 fishing vessels that have been caught encroaching on the Chilean Nazca-Desventuradas protected area since 2018. In October 2020, while the fleet approached the Chilean EEZ from the north, the Chinese embassy in Santiago barely acknowledged Chile's concerns. Meanwhile the embassy arranged a special "China edition" of the magazine La Tercera full of pro-China articles written by prominent academics and current and former Chilean politicians, including former President Eduardo Frei. After more than a week without tweeting anything, the Chinese embassy's Twitter account squeezed this statement in among nine other tweets distributing the La Tercera articles:

As a responsible country, China always attaches great importance to the protection of the environment and resources of the ocean, and exercises strict supervision and controls on ships that are in overseas operation and requires companies to strictly obey the relevant laws. (Chinese Embassy in Chile, 2020)

At least this particular tweet about the Chinese fishing fleet did not kick off a twitter spat between the United States and Chinese embassies like what occurred a month prior in Peru. Although the Chinese embassy's attempt to bury the topic in good press was far short of subtle diplomacy.

A similar example of Chinese diplomatic maneuvering occurred when several Chilean congressmen flew to Hong Kong in 2019 to meet with leaders of the pro-democracy demonstrations. The former Chinese ambassador in Santiago responded with a scathing op-ed in Chile's prominent newspaper El Mercurio and released it with a twelve-page special section full of positive articles (Xu, 2019). The Chileans seem to have understood the message -no politicians have made further comments about Hong Kong or Xinjiang. Meanwhile, the Chinese made it a point to avoid commenting on the political unrest in Chile that began in October of 2019. Fear of economic blowback has changed the Chileans willingness to openly criticize China. This is where the risks lie for LAC as their economic ties become further intertwined with the Asian giant.

\section{Chinese activity in the Chilean mining industry}

The Chilean mining sector has played a critical role in the Sino-Chilean relationship since the 1990s. Chilean copper is a critical resource for Chinese construction projects and electronic goods and accounts for almost 35\% of China's copper imports. Meanwhile, more than $85 \%$ of Chilean exports to China are copper and other ores. In addition to the "red gold", Chile has vast reserves of lithium and molybdenum. The former will play a huge role in combating climate change as lithium-ion batteries are employed in electric cars and "green" industrial power storage. Meanwhile, the latter is a byproduct of copper mining and improves the quality of many alloys, to include steel, stainless steel, and high-tech superalloys.

Since the pre-revolutionary era, the mining sector has been an important source of wealth and taxes for the country at the end of the world. Many of Chile's historical cities along its northern coast were established by the Spanish empire to access Chilean gold and silver. At the end of the 19th century, Chile started to accrue wealth for the first time by mining saltpeter in territory seized from Peru after the War of the Pacific. Then, during the early twentieth century, vast copper reserves in the north attracted FDI from the United States and quickly became a major source of tax revenue. During the Cold War, copper was used to fund a large portion of the country's military budget under the Ley Reservada del Cobre enacted in 1958 under president 
and former general Carlos Ibáñez del Campo. Remarkably, despite the fact that Chile has not fought a war since the 1880s, it wasn't until July of 2019 that Chile passed a law to slowly phase out the requirement that guarantees $10 \%$ of the profits from copper exports are used to fund the Chilean military.

Chile's copper has one distinguishing factor that separates it from other industry in Chile -it is state owed. The nationalization process was started under the center-left Eduardo Frei Montalva administration (1964-1970) as Chile began to purchase shares of the foreign companies operating in Chile under a process called "nacionalización pactada" or agreed nationalization. Then, early in the Allende years, Chile's congress overwhelmingly voted to completely nationalize Chilean copper and place full ownership of all Chilean copper operations under the Chilean National Copper Corporation (Codelco - Corporación Nacional del Cobre de Chile). Even though the move alienated US interests, the military government only further entrenched the state ownership of copper by cementing the change in an official decree on April 1, 1976. Chile's neoliberal reforms touched nearly every aspect of their economy, but Codelco has remained state-owned since its nationalization in 1971. In addition, Codelco has become a major source of pride for Chileans, a major source of income for their government, and an increasingly more important player in Sino-Chilean relations. As China began to implement its "Go Out" strategy in Latin America in the early 2000s, Chile's lucrative copper industry was extremely attractive.

The first chance for the Chinese to invest in the Chilean mining sector arose in 2006, just after the two countries had signed their FTA (which still did not include provisions on investment). Codelco was preparing to begin work on a new mining project in the Antofagasta region named after the Chilean poet and Nobel laureate Gabriela Mistral. But the Chilean SOE was short on cash and unwilling to take on more debt. It needed a partner with cash on hand and found the perfect match in China Minmetals. The two SOEs signed an agreement in February of 2006 in Beijing, formally creating a joint venture called the Copper Partners Investment Company (CuPIC).

In the agreement, Codelco and Minmetals each agreed to contribute US\$ 110 million, which would be supplemented by an additional US\$330 million loan from the China Development Bank (CDB). In return, Codelco agreed to sell the Chinese 55,750 cathodes of copper per year for 15 years (from June 2007 to May 2021) at a fixed price. That price was set by Codelco and a group of independent consultants, and while it was never officially made public, it was suspected to be set between US\$ 1.03-1.05 per pound (Pérez-Cueto \& Novoa, 2014) (Codelco, 2006).

Initially, CuPIC was a large success. The Gaby mine project was finished in 2008 and production has reached 150 to 170 thousand tons of fine copper per year. But as the China Boom continued to push commodities prices higher, the decision to fix a copper price for fifteen years became a major controversy in Chile. As the price of copper skyrocketed -it has averaged more than US\$ 3 per pound since the agreement was reached and peaked at US\$ 4.6285 per pound in 2011- the public scrutiny on the deal increased. By the end of 2008, the Chilean Chamber of Deputies (the lower house of Chile's bicameral Congress) had initiated a series of investigations into the lopsided deal. According to their 2014 report on the subject, Codelco had lost US\$ 2.98 billion since the agreement's inception relative to the market price of copper.

However, there was a second part of the deal that would lead to even more controversy. While it initially seemed that the Chinese had gotten a great deal, their ultimate goal was to gain an owning stake in the mine. During the negotiations, Codelco agreed that if it sold the Gaby mine, Minmetals had first refusal on a 25\% stake and could compete for the remaining $24 \%$ that would be made available. Codelco would remain the majority holder with a $51 \%$ stake (Codelco, 2005). The Chinese understood this to mean that the Chileans would put the mine up for sale shortly after operations began in 2008. Meanwhile, the Chileans understood the clause to be 
conditional and never stated that the mine would definitely be publicly offered. As the price of copper continued to go up, the political viability of a sale to the Chinese steadily declined. Ultimately, due to political pressure and the threat of a strike by the labor union, Codelco decided to cancel the public offering. Fortunately, according to then ambassador Fernando Reyes Matta, the two SOEs were able to come to an agreement in September of 2008 and avoid a diplomatic conflict that could have soured otherwise good relations. There were no public statements from the Chinese embassy or diplomatic pressure applied to politicians in Congress (Méndez Morán, 2018, p. 350).

The CuPIC-Gaby mine controversy has had broad sweeping implications for Chinese investors ever since. Many Chinese business leaders cite the Codelco-Minmetals fallout as a turning point in the Asian giant's perception of Chile. From their perspective, if Codelco can break an agreement with a massive Chinese SOE, why would private companies invest in Chilean mining. While writing his 2018 book on China in LAC, Mexican journalist Daniel Méndez Morán interviewed China's trade and economic representative to Chile Liu Rutao, who stated, "There are no complaints, there is no hatred, it's not like that. But when Chileans ask me: 'Why is there no Chinese investment in Chilean mining?' I always answer them: 'There was. China Minmetals came to Chile before going to Peru, but since they were abandoned by Chile, they left"' (pp. 350351). This one incident slowed Chinese investment in Chile across all sectors for nearly a decade.

The second and only other significant investment the Chinese have made in the Chilean mining sector occurred in 2018 when Tianqi Lithium Corporation, a private Chinese company and global supplier of lithium products, purchased a 32\% stake in the Chilean Chemical and Mining Company (SQM - Sociedad Química y Minera de Chile). The sale of the SQM shares was required by regulators when two mining companies merged to form the Canadian conglomerate Nutrien. As a result, Tianqi offered US\$ 4.07 billion for the $32 \%$ stake in SQM as "part of an aggressive global expansion aimed at securing leadership in the lithium market" (MINING.com, 2021) $)^{5}$. Since lithium is the lightest and most electronegative metal in the world, lithium-ion batteries are the lightest and most energy dense on the market (Baumgartl, et al., 2020, p. 35). Therefore, lithium-ion batteries are pivotal to the global transition to electric vehicles. The purchase of SQM places China in control of the lithium market just as the pivot toward electric vehicles begins.

Like the CuPIC deal, this purchase was not without controversy ${ }^{6}$. In March of 2018, during the final days of the Michelle Bachelet administration, Eduardo Bitran, then head of the Chilean Production Development Corporation (CORFO - Corporación de Fomento de la Producción de Chile), filed an anti-trust suit against the purchase of SQM claiming the Chinese company would gain a monopoly on global lithium supply. The Chinese embassy in Chile immediately accused Bitran, a political appointee, of politicizing a deal between private companies. In an interview, Chinese ambassador $\mathrm{Xu} \mathrm{Bu}$ claimed, "Bitran's actions and expressions have turned this totally commercial action into a political matter and may leave negative influences on the development of economic and commercial relations between both countries" (Osorio, 2018). The aforementioned Liu Rutao later told Reuters that Bitran had succumbed to political pressure from foreign lobbyists (Iturrieta \& Sherwood, 2018). Ultimately, the deal was approved by the Chileans, but the message was clear. Ten years after quietly accepting their fate in the Gaby mine controversy, China has clearly changed its approach under

\footnotetext{
${ }^{5}$ It has been reported that the Tianqi deal generated more than one billion US dollars in taxes for the Chilean state. See: InvestChile (2019)

${ }^{6}$ In fact, SQM has a complicated history in the world of Chilean politics. The director is Julio Ponce Lerou, the forestry engineer and former son-in-law of Augusto Pinochet who was implicated in the Caso Cascadas controversy in in 2014. Ponce Lerou ran CORFO (which was responsible for SQM) during the dictatorship and later led the private group that purchased SQM when it was privatized in 1987.
} 
Xi Jinping. Chinese diplomats are no longer afraid to openly use diplomatic pressure to advocate for the PRC's economic interests.

Overall, the Chilean's approach to its mineral resources has led to significant economic progress since the return of democracy in 1990. Excellent fiscal policy over three decades has led to an average GFCF of $23.14 \%$ (the highest rate in LAC over that time) and the elevation of more than $40 \%$ of its population out of poverty. But there are downsides to over reliance on the mining sector, and the Chinese often exacerbate these issues. For example, mining is a capital-intensive industry that does not create many jobs (Stallings, 2020, p. 68). In Chile, mining accounts for nearly $55 \%$ of all total exports, but only $9 \%$ of labor (Baumgartl, et al., 2020, p. 15). This ratio can be improved through value-added processes like smelting, but China's development strategy is to import raw materials in their most crude forms and then refine them on Chinese soil using their massive labor force ${ }^{7}$. This is true for both copper and lithium: Chile produces $28 \%$ of the world's copper but only smelts $8 \%$, meanwhile China produces $9 \%$ and smelts more than a third (36\%). Similarly, while China only mines $8 \%$ of the world's lithium, it processes more than $38 \%$ (Baumgartl, et al., 2020, pp. 22, 35). The best long-term strategy for Chile and its mining sector would be to invest in value-added production now and use the profits to transition from nonrenewable industries altogether (Gachúz, 2012, p. 142).

\section{The influence of Chinese markets on Chilean agriculture}

Like mining, Chile has a long and deep connection with the exportation of agricultural products. Prior to independence, Chile was an important source for wheat throughout the Spanish Americas. In addition, the California gold rush that began in 1849 drove demand for year-round wheat on the US west coast and Chile became the de facto supplier during the North American winter. Prior to the $20^{\text {th }}$ century, Chile's affluent class accrued their wealth by growing food on their haciendas and selling it for export in global markets. While Chile's economy has evolved significantly over the past century -Chile has become a regional leader in services, for examplethe importance of agriculture cannot be overstated. The agroindustry is responsible for about $5 \%$ of GDP and employs more than $15 \%$ of Chile's labor force.

Chile was destined to play an important role as a global food provider due it its geography. While it is a relatively large country -just slightly larger than France and nearly twice the size of California- and has a relatively small population. According to UN population data, Chile has a population of just 18.9 million, of which $40 \%$ live in the Santiago metropolitan area. Again, compared with France (65.2 million) or California (39.4 million) -a country and US state with rich agricultural industries- Chile certainly has the land available for use in agriculture. While not all of this land is available for agricultural use due to the mountains and the desert, the land that is available is very diverse. From north to south, Chile is more than 4,300 kilometers long, stretching through extremely diverse climatic zones. This creates the conditions for a wide variety of agricultural products, especially fruits, to include cherries, blueberries, plums, grapes, apples, avocados, kiwifruit, pears, and citrus (Kelly, 2017). All of these products are experiencing increases in demand due to a growing middle class across the developing world.

In addition to having diverse agricultural land available, there is a second element of Chilean geography that makes it even more favorable to agricultural export: isolation. The country has natural barriers that protect its crops from pests and plagues. Most famously, Chile's prized carménère grape escaped the phylloxera plague that struck Europe in 1867. As Chile's trade representative in Shanghai César Suárez describes, "Chile is protected due to its natural barriers: the Andes to the east, the Pacific Ocean to the west, the arid Atacama Desert to the north, and

\footnotetext{
${ }^{7}$ Other examples of this include the refining of Ecuadorian and Venezuelan crude in China, and the refusal to buy processed soy from Argentina.
} 
Antarctica to the south. In essence, Chile is a phytosanitary island" (Produce Report, 2016). This phytosanitary advantage was appealing to both the United States and the Chinese during bilateral FTA negotiations and allowed Chilean agricultural exports to gain favored market access to both countries.

The final geographic element to the Chilean agricultural success story involves timing. Since Chile is situated in the Southern Hemisphere, its producers can fulfill demand for fresh produce during the Northern Hemisphere's winter, when global supply is at its lowest. In fact, many of Chile's fruit exports to the United States and China meet demand that domestic growers cannot meet during the North American winter months.

All of these advantages make Chile a natural partner in China's globalized strategy to feed its 1.4 billion citizens. As the Chinese middle class has grown, demand for healthier food options has exploded. While domestic growers in China must contend with polluted water supplies and exhausted soil, many foreign importers can offer organic, sustainably grown options. For exactly this reason, Chinese consumers have a preference for imported fruit despite its slightly higher price tag. In 2019, imported fruit totaled approximately 6.83 million tons with a total value of US\$ 9.5 billion (Jing, 2020).

In order to tap into this huge market, Chile has executed a strategy that combines the strengths of the private and public sectors. ProChile, the export-promotion branch of the ministry for foreign affairs, focuses on trade policy and high-level promotion. The agency has an agricultural representative in the embassy in Beijing and trade offices in Beijing, Guangzhou, Hong Kong, and Shanghai ${ }^{8}$. These offices help Chilean businesses and trade cooperatives advertise, identify trends, and develop long-term strategies (González, 2018, p. 11). ProChile's most important partner in the private sector is the Chilean Fruit Exporters Association (ASOEX - Asociación de Exportadores de Frutas de Chile), a non-profit private entity that has represented Chile's fresh fruit growers and exporters since 1935. The association represents more than 350 producing and exporting companies and constitutes more than $95 \%$ of fresh fruit exports (ASOEX, 2021). The ProChile-ASOEX partnership has combined advertising dollars to target the most lucrative parts of China's produce market (González, 2018, p. 11). And this partnership has paid off. In 2018, Chile became the largest exporter of fresh fruits to China, a remarkable feat considering the size and geographic advantages of competitors like Thailand, Vietnam, the Philippines, the United States, New Zealand, and Australia (Produce Report, 2020).

In addition to the public-private partnership, the Chile-China FTA has played a major role in Chile's success. Since Chile was granted privileged sanitary and phytosanitary status in the initial FTA, China streamlined the approval process for additional types of fruits to enter the Chinese market. While the FTA initially only included provisions for six products -apples, cherries, grapes, plums, cheese, and chicken products (Ellis, 2009, p. 38)- ProChile has gained approval for a new fruit every year since (González, 2018, p. 11). For example, after nearly two decades of negotiations and despite the ongoing pandemic, Chilean citrus gained access to the Chinese market in May of 2020. This could be a game changer for both the Chilean producers and Chinese consumers once global trade renormalizes after the pandemic. In 2019, China imported 328,000 tons of citrus fruit from the Southern Hemisphere while Chile exported 340,000 tons, nearly all of which went to the United States (Produce Report, 2021).

But citrus has a long way to go to catch Chile's number one agricultural export. As the aforementioned César Suárez says, "cherries are the queen of our fruit sales in China" (Produce Report, 2016). And for good reason -Chilean cherries have reached a total value of over one billion US\$ annually. The success of Chilean cherries offers an example of what can happen at the confluence of all of the aforementioned advantages. Cherries were given preferential

\footnotetext{
${ }^{8}$ For comparison, Chile has seven trade offices in the United States.
} 
phytosanitary treatment in the FTA, heavily promoted by ProChile and ASOEX, and benefit by arriving during China's winter season. In fact, Chilean cherries arrive just in time for the Chinese New Year and have become a staple due to their red color (red is thought to bring luck and happiness to the new year) (Olave, 2020). In 2018, ProChile launched the "Enjoy your Red Moment" marketing campaign focused on expanding year-round consumption of Chilean cherries (González, 2018, p. 11). The campaign has been so successful that ProChile added red wine to the campaign in 2020. The wine industry is hoping to mimic the cherry's success, as fresh cherry imports reached US\$ 1.2 billion in 2019 (Jing, 2020). The red fruit has become so critical to Chile's annual exports that special consignments are shipped directly to China, cutting the journey down to just twenty-two days and ensuring delivery for the most important holiday of the year (Kelly, 2017).

Given the size of China's market and Chile's reliance on it for exports, there is a clear risk of dependency by Chilean fruit growers and exporters. More than $90 \%$ of Chilean cherries are exported to China and the percentage has increased several years running. Since cherries are an important agricultural commodity, and as Barbara Stallings (2020) points out, commodities are most "susceptible to price shocks" (p. 11), the Chilean cherry business has been vulnerable. Stallings recommends diversification, which in the case of Chilean cherries may be necessary given what occurred in January of 2021. On January 21st, a local public health agency in China's eastern Jiangsu province circulated a statement claiming that cherries imported the previous month had tested positive for traces of Covid-19. While the claims were never substantiated by the CCP or directly linked to Chilean cherries, demand for the red fruit plummeted just days before the Chinese New Year celebration (Tan, 2021). According to ASOEX, negative mentions of Chilean cherries began trending on social media. The situation became "critical" as demand dropped more than $95 \%$ in one week (Sánchez, 2021). Buyers were offering just 80 yuan for fivekilogram crates that normally fetched up to 300 yuan in the weeks prior to New Year. As a result, ProChile, ASOEX, and the Chilean ambassador Luis Schmidt launched a US\$ 1.5 million campaign to reinforce Chile's high sanitary standards and deny that the contaminated fruit originated in Chile (Tan, 2021). Unfortunately, Chilean exporters and producers faced a significant drop in revenue as a result of one piece of unsubstantiated bad press.

This example shows the vulnerability of export markets when they become overly reliant on one customer. While the CCP was certainly not responsible for the market shock in this case, they have shown a propensity in recent years to use their large consumer market as diplomatic leverage. One example is the series of tariffs the CCP levied on Australian barley, copper, and coal in 2020 in response to Canberra's call for an investigation into the origins of the coronavirus (Russell, 2021). One leading observer of China in Latin America has gone so far as to call this tactic a form of "mercantilism with Chinese characteristics" (Ellis, 2020). ${ }^{9}$ While Australian barley growers were able to replant their fields to meet demand in other agricultural sectors, Chilean cherry and citrus growers would not have that kind of flexibility. In light of this new aggressive diplomacy, Chile's agricultural sector would be wise to seek further diversification of export markets.

\footnotetext{
${ }^{9}$ Leading economists like Paul Krugman (2009) have accused China of using mercantilist tactics for several years by, "keeping the renminbi weak through a combination of capital controls and intervention, leading to trade surpluses and capital exports in a country that might well be a natural capital importer". However, the use of tariffs has become a new tactic under the Xi Jinping regime and often to protect political interests, not economic interests (this example with Australia is the clearest evidence of this to date). As Evan Ellis (2020) writes, "Today, it's China, once victims of mercantilism themselves, who are exploiting international trade and investment to reorient the world to their advantage through a predatory coordination between their national champion companies, well-resourced financial partners, and their government". Since China has grown more authoritarian, its use of tariffs to protect its political interests is very concerning for countries embedded in its global supply chains.
} 


\section{Chinese Foreign Direct Investment}

When the Chilean government was aggressively pursuing an FTA with the Chinese during the early 2000s, one of the main justifications was the promotion of Chinese FDI. Chile hoped the increased economic and diplomatic relations would encourage businesses in Beijing and Shanghai to look at Chile as their bridge to the rest of Latin America (Frohmann \& Wilhelmy, 2016). But Chinese investment arrived much slower than many had hoped. According to statistics compiled by ECLAC and InvestChile, Chile averaged US\$21.27 billion in total incoming FDI per year between 2010 and 2016. This meant that a country with just 3\% of LAC's population was receiving 11.2\% of the region's incoming investment (Méndez Morán, 2018, p. 344). But that FDI originated overwhelming from companies in the United States, Canada, and Europe. During that same time period, Chinese OFDI to Chile never exceeded US\$ 750 million.

There are many reasons why the Chinese got a slow start in Chile; not least among them was the experience Minmetals had in 2008 with the Gaby mine. In fact, following the CodelcoMinmetals fallout, Chinese mineral companies stopped engaging with Chile because they wanted to buy mines, not pay for exploration. By 2008, the Chilean mining sector was well established and extremely profitable, therefore mine projects were not going up for sale and the only possibilities for investment were in new exploration. Outside of the mining sector, several other factors impeded Chinese investment, for example the relatively high cost to do business in Chile, the complicated and legalistic character of the bidding process, and the small but open consumer market (Méndez Morán, 2018, pp. 345-346). Furthermore, the China-Chile FTA has allowed Chinese manufacturers to export their goods to Chile tariff-free, therefore Chinese firms have prioritized building factories in the bigger markets in LAC in which China does not have an FTA, for example Argentina or Brazil (Méndez Morán, 2018, p. 346).

All of this started to change within the past five years. Macroeconomic factors have made Chile's neighbors less-appealing destinations as much of the region slipped into a post-boom recession. Meanwhile, the relative stability of Chile, Peru and Colombia have made them the popular destinations for investment. The explosion of Chinese investment is clear in the numbers released by InvestChile: Chinese investment in 2016 totaled 5 projects and US\$ 310 million, but just two years later totaled 20 projects and more than US\$ 1.8 billion (Cárdenas, 2019). Meanwhile, China was the number one source of FDI in 2019 with US\$ 4.85 billion in active investment and suffered only a slight slip due to the pandemic in 2020 with a total of US\$ 3.89 billion (Pizzarro \& Villagrán, 2020; InvestChile, 2021).

The main reason for this explosive growth in FDI is the diversification across several key sectors in the Chilean economy, to include agriculture, transportation infrastructure, digital and telecommunications services, and energy. As discussed in the previous section, investment in foreign agroindustry has a natural appeal for China as it solidifies its globalized food security strategy. In Chile, that has meant the recent purchases of vineyards and a salmon farming company. One of the first major investments came in 2010 when the SOE COFCO purchased 600 hectares from a family-owned vineyard in the Colchagua valley (Cominetti, Tapia, \& Moreno, 2010). Since then, China has become the primary market for Chilean wine exports while Chile is third in Chinese imports behind only France and Australia (González, 2018, p. 12). As word of Chilean wine's great value continues to spread, there have been a flurry of similar purchases during the recent boom in FDI, headlined by Yantai Changyu Pioneer Wine who bought $85 \%$ of the Bethia group for US\$ 50 million (Indomita, Santa Alicia and Dos Andes vineyards) and the Jiangsu Yanghe Distillery Group who purchased 12.5\% of Viña San Pedro Tarapacá for US\$ 65 million (Pizzarro \& Villagrán, 2020; InvestChile, 2019). Although, the largest purchase in the agro-industrial sector to date was not wine, but rather salmon fisheries. In June of 2019, Joyvio invested US\$ 880 million to purchase Australis Seafoods, which represents about 9\% of Chile's salmon production. From the Chinese perspective, investment in salmon and wine production make good business sense since they are value-added products. In fact, some Chilean vineyards are marketing individual bottles of wine in China for more than US\$2,000! (Flannery, 2018) 
Meanwhile, from the Chilean perspective, FDI of this type is welcome as the value-added portion is conducted on Chilean soil and with Chilean labor.

Table 1: Major Chinese FDI in Chile (2008 - 2020)

\begin{tabular}{|c|c|c|c|c|}
\hline Date & Investing Company & Project or target company & Destination sector & $\begin{array}{c}\text { Investment } \\
\text { (US\$ } \\
\text { millions) } \\
\end{array}$ \\
\hline 2008 & China Development Bank & China Development Bank & Financial sector & 33.5 \\
\hline 2009 & $\begin{array}{c}\text { Foshan City Shunde Rixin } \\
\text { Dev. Co. with China } \\
\text { Minmetals } \\
\end{array}$ & $\begin{array}{l}70 \% \text { exploitation rights to an } \\
\text { iron ore deposit (Vallenar) }\end{array}$ & Mining & 550.0 \\
\hline 2012 & $\begin{array}{c}\text { Xinjiang Goldwind Sci. \& } \\
\text { Tech. }\end{array}$ & Xinjiang Goldwind & Energy & 190.0 \\
\hline 2014 & Envision Energy & Envision Energy & Engines \& Turbines & 33.0 \\
\hline 2015 & JA Solar & JA Solar & Energy & 286.0 \\
\hline 2017 & Pacific Hydro & $\begin{array}{c}\text { Hydroelectric Utilities } \\
\text { Chacayes }\end{array}$ & Real Estate & 44.2 \\
\hline 2017 & $\begin{array}{l}\text { Yantai Changyu Pioneer } \\
\text { Wine }\end{array}$ & $\begin{array}{l}\text { Bethwine Bodegas Bethia } \\
\text { Group }\end{array}$ & $\begin{array}{l}\text { Agricultural } \\
\text { Products }\end{array}$ & 60.0 \\
\hline 2017 & Sky Solar Holdings, Ltd. & $\begin{array}{l}24 \text { MW Portfolio of small } \\
\text { generator solar projects }\end{array}$ & Energy & $1,360.0$ \\
\hline 2018 & China Southern Power Grid & $27.7 \%$ of HQI Transelec & Energy & $1,300.0$ \\
\hline 2018 & Jiangsu Yanghe Brewery & $\begin{array}{c}12.5 \% \text { of Viña } \\
\text { San Pedro Tarapacá SA }\end{array}$ & Wine & 64.8 \\
\hline 2018 & Pacific Hydro & & Energy & 140.0 \\
\hline 2018 & $\begin{array}{c}\text { China Three Gorges } \\
\text { Corporation }\end{array}$ & $\begin{array}{c}\text { Atiaia Energía / } \\
\text { Rucalhue Hydro Project }\end{array}$ & Energy & Unknown \\
\hline 2018 & Tianqi Lithium Corp & $\begin{array}{l}\text { Sociedad Química y } \\
\text { Minera de Chile S.A }\end{array}$ & Lithium & $4,066.0$ \\
\hline 2019 & Huawei & Huawei Chile & Communications & 100.0 \\
\hline 2019 & $\begin{array}{c}\text { Joyvio Agriculture } \\
\text { Development } \\
\end{array}$ & Australis Seafood & Food & 889.0 \\
\hline 2019 & $\begin{array}{l}\text { China Road and Bridge } \\
\text { Corporation *with Puentes } \\
\text { y Calzadas (Spain) }\end{array}$ & $\begin{array}{l}\text { Hospital construction in the } \\
\text { Maule region (Cauquenes, } \\
\text { Constitución and Parral) }\end{array}$ & Medical & 224.0 \\
\hline 2019 & $\begin{array}{c}\text { State Grid Corporation of } \\
\text { China }\end{array}$ & Chilquita Energía & Energy & $2,230.0$ \\
\hline 2020 & $\begin{array}{c}\text { State Grid Corporation of } \\
\text { China }\end{array}$ & $\begin{array}{l}\text { Compañía General de } \\
\text { Electricidad }\end{array}$ & Energy & $3,000.0$ \\
\hline 2020 & $\begin{array}{c}\text { China Railway Construction } \\
\text { Corporation }\end{array}$ & $\begin{array}{c}\text { Construction of Route } 5 \\
\text { (Talca-Chillán) }\end{array}$ & Infrastructure & 804.0 \\
\hline
\end{tabular}

Author's own rendering based on information from multiple sources, including: Red ALC-China (2020), Méndez Morán (2018); InvestChile; La Tercera; Revista Electricidad, and various other media reports

As China continues to "export" its overcapacity in construction to other parts of the developing world, countries with ambitious concession portfolios are extremely appealing. As of late 2020, the Chilean Ministry of Public Works had a portfolio of concessions worth more than US\$14 billion (Zhu, 2020). Many of these projects are expansions of Chile's aging highways, but there are larger projects like the recent expansion of the port in San Antonio and the possible 
construction of a rail system between Santiago and Valparaíso (InvestChile, 2019). Chile hopes to use their public works projects as a form of government stimulus that will infuse money into the economy as it recovers from the pandemic. But will Chinese companies try to bring in their own labor to execute contracts paid by the Chilean taxpayer? In the post-pandemic world, Chile must ensure these projects benefit their local economies by hiring local workers.

One of the most exciting areas for Chinese FDI is in the services sector, in particular telecommunications and finance. Chile has positioned itself as a potential digital hub for Latin America due to its excellent telecommunications infrastructure and highly talented workforce. The country has had great success drawing in foreign innovators with its incentive programs like Start-Up Chile, which has helped launch nearly two thousand start-ups with a combined valuation of $\$ 2.1$ billion dollars (Start-Up Chile, 2021). China's booming tech industry recognizes the opportunity. Chinese telecommunications giant Huawei has built two data centers in Santiago and recently concluded a feasibility study for a trans-Pacific fiber cable connecting Chile to Shanghai. Although, the Chilean Telecommunications Undersecretariat (SUBTEL) chose to run the cable through Auckland to Sydney, the cable and the data centers put Chile in position to attract more FDI in the coming decades. In the realm of finance, the China Construction Bank and the Bank of China both have offices in Santiago meanwhile, the Central Bank of Chile is the only Renminbi clearinghouse in Latin America. These advantages provide further incentive for Chinese FDI to invest in Chile and deepen the economic ties between Chile and its largest trade partner.

While investment in agriculture, infrastructure, and services is important, the most interesting development involving Chinese FDI in Chile is in the rapidly evolving energy sector. As the head of the China Desk for InvestChile Zhu Wenjie (2020) writes, "the acquisition of existing assets in the energy sector is the fastest way for Chinese companies to grow in size and global market share". The buying frenzy began in 2018 when the SOE China Three Gorges Corporation (CTG) acquired the Rucalhue hydroelectric project in the Bío-Bío Region. CTG is also seeking permits for the Río Bueno hydroelectric project in Los Ríos Region and exploring options in Chilean Patagonia. This interest in hydroelectric power is part of a larger movement by the Chinese to get involved in green energy research, development, and deployment. Moreover, interest is expected to grow following Xi Jinping's declaration in September 2020 that China will be a net-zero emitter of carbon by 2060. The Chinese view Chile as an opportunity due to what Zhu describes as the country's "favorable conditions for the development of non-conventional renewable energies" (2020). Chile has become a leading advocate for green hydrogen technology due to the ideal geographic conditions of its northern desert. In addition, the country inaugurated the first geothermal power plant in South America in September of 2017. As the global economy shifts further toward green energy, Chile is uniquely positioned to lead Latin America forward.

China's two largest utility companies have taken notice. Since early 2018, the SOEs China Southern Power Grid Company (CSG) and the State Grid Corporation of China (SGCC or State Grid) have been aggressively bidding on sales of the Chilean power grid. CSG entered the market first when it bought $27.8 \%$ of Chile's largest electric transmission system, Transelec, in March of 2018 for US\$ 1.3 billion (De la Jara, 2018). The high-tension electricity system provider operates more than $10,000 \mathrm{~km}$ of transmission lines in Chile, covering all of Chile north of Patagonia and approximately 98\% of the country's population (Transelec, 2021). The purchase was seen throughout Chile as a win-win since the Chilean power grid is in need of major modernization and CSG has implemented more strict management standards (for example, by limiting the grid to six hours of outage per year -the standard in southern China- down from 20 hours) (InvestChile, 2019).

Following CGS's move into power distribution in 2018, State Grid bought two of Chile's four largest electricity generation companies in October 2019 and November 2020 respectively. In the first deal, State Grid bought Chilquinta Energía, the energy provider for the Valparaíso Region, for US\$2.23 billion (Nogales Toledo, 2019). In the second, it purchased Compañía General de Electricidad (CGE) and its subsidiaries for about US\$ 3 billion. As of writing, the 
Chilean National Economic Prosecutor's Office (FNE - Fiscalía Nacional Económica) was meeting with executives from State Grid to finalize the latter deal which would put a Chinese SOE in charge of power generation for ten of Chile's sixteen regions and $57 \%$ of its population ${ }^{10}$. Testifying before a congressional economic commission, FNE director Ricardo Riesco stated he can legally stop the deal only if it interferes with the "promotion, defense, and protection of free competition". It is not within the FNE's scope to consider factors like national security. In addition, the FNE rarely rejects cases outright: of the 135 cases it has ruled on, only three have been rejected (Guzmán, 2021). Therefore, it is widely expected that the deal will be approved by Riesco in 2021. While vertical integration is strictly prohibited (for example, one company could not own a generation company like CGE and a distribution company like Transelec), it is not illegal to own the power generation company for multiple regions. But it is precisely here where the debate regarding Chinese SOEs becomes most contentious.

What role does the CCP play in the strategic decisions made by its SOEs? Should the Chilean FNE view CSG and State Grid as two separate competitors? Or does their connection to the CCP mean they are inextricably linked? These are among the questions Chilean lawmakers confront in the upcoming State Grid decision. Approval of the deal would mean that the CCP's two state-owned electrical companies would control a significant portion of Chile's electrical grid. Members of Chile's Lower House would like to draw the line here. While they may not be able to block this sale, they have proposed a bill that would require future foreign SOEs investing in certain strategic sectors to receive a two-thirds majority approval from Congress (Guzmán, 2021). While approval of the law is extremely unlikely due to the second and third order effects on FDI more broadly, it is safe to assume that the Chinese would react negatively to any legislation targeting Chinese SOEs.

\section{Analysis and Final Reflections}

When compared to other countries in LAC, Chile has been one of the most successful in its engagement with a rising PRC. The expansion of exports in the 2000s provided the means to invest in education, infrastructure, and innovation. In addition, sound fiscal policy and high copper prices helped the Chileans weather the global financial crisis better than many other South American nations. As a result, average annual GDP growth during the commodities boom from 2003-2013 was 4.69\% and GDP growth per capita averaged 3.61\%. However, Chinese economic policy has shifted to emphasize domestic consumption and commodities prices have cooled off. This can be seen in the drops in Chile's GDP growth and per capita growth from 2014 to 2019 , which slowed to $2.0 \%$ and $0.72 \%$ respectively ${ }^{11}$. Is this cyclical growth pattern simply the result of Chile's commodity driven economy, or do these numbers demonstrate a more perilous tendency towards a dependent relationship?

During the boom years, Chinese economic and foreign policy still centered around development as the Asian giant focused on capturing globalization's benefits. Meanwhile, the Chileans became champions of free trade as a means to increase exports. These interests led the two nations to negotiate an FTA -the first bilateral agreement of its kind signed by the Chinese- and then release their private sectors and SOEs to drive integration, investment, and growth. Bilateral trade exploded, from just under $\$ 4$ billion in 2003 to nearly $\$ 35$ billion in 2013 . However, the growth of bilateral trade began to level off following the rise of Xi Jinping. In his

${ }^{10} \mathrm{CGE}$ is responsible for power generation in the following regions in Chile: Arica and Parinacota, Tarapacá, Antofagasta, Atacama, Coquimbo, O'Higgins, Maule, Nuble, and Biobío (Álvarez Pelegry \& Larrea Basterra, 2018)

11 All data in this section is from the World Bank's World Integrated Trade Solution: https://wits.worldbank.org/ 
first year as chairman of the $\mathrm{CCP}, \mathrm{Xi}$ announced the shift to domestic consumption, the China boom ended, and global commodity prices began to drop. For the Chileans, deepening integration with the Chinese economy had not guaranteed consistent economic growth.

In examining what early dependency scholars Fernando Henrique Cardoso and Enzo Faletto (1979) call "situations of dependency" (p. xxiii), this article has focused primarily on two of Barbara Stallings' mechanisms of dependency: markets and linkage (2020, pp. 10-16) (1992, pp. 48-58). Despite their strong institutions, the Chilean's embrace of free trade policies and open markets has led to some concerning trends as China continues its economic expansion. The formation of a market dependency is clear considering that by 2018 China represented $23.6 \%$ of Chilean imports and an astounding 33.5\% of Chilean exports. Furthermore, the Chileans export nearly half of their copper, ore, and slag to China and have become heavily reliant on Chinese consumers to support their agricultural products like cherries and wine. In the case of cherries, the dependence was exposed in January of 2021 when rumors of contaminated cherries spread on social media and demand for Chilean cherries plummeted. With more than $90 \%$ of a US\$ 1.58 billion cherry harvest going to one country, ProChile and ASOEX would be wise to leverage their phytosanitary advantages and diversify their export markets in the northern hemisphere.

Cardoso and Faletto (1979) highlighted the risk that market dependency carries with it. They wrote that situations of dependency hinder self-sustaining growth since the hegemonic country determines the growth areas, not the dependent country. Stallings (2020) went further by warning that the weaknesses of a dependent market are often exposed during economic slowdowns (pp. 10-11, 68). In this sense, Chile was vulnerable to the slowdown in 2014 since its copper industry had become less diversified and it never made significant progress in value added exports. This was in some part due to the PRC's unwillingness to invest in value added production on Chilean soil and instead were importing raw materials in their most basic form -in this case with zero tariffs due to the FTA- and utilizing Chinese labor to do the value-added production in China. As the PRC's economic expansion continues to outpace global growth (China may represent up to $40 \%$ of global GDP by mid-century) and an authoritarian PRC continues to employ mercantilist foreign policies like those seen during the pandemic, this market dependency must be closely monitored by Chilean policy makers.

While a certain level of market dependency is normal when interacting with an economic superpower, the second mechanism of dependency developing in this relationship requires more careful analysis: linkage. According to Barbara Stallings (2020), linkage is "the set of relationships $[\ldots]$ whereby actors in dependent countries come to identify their interests with those of a more powerful country" (p. 14). In this sense, the Chinese have pursued their globalization driven development model based on importing raw materials and commodity foods and exporting manufactured goods. Meanwhile, they have fostered the thinking among Chilean elites that this model is widely beneficial to Chile and, therefore, the country should continue to focus on exports and trade liberalization. It is for this exact reason that Stallings claims that the three FTAs in LAC are more about linkage than about markets (pp. 67-68). In order to promote this model, the PRC has used an array of tools to further entrench trade relationships and by extension increase linkage with its trade partners. These tools include executing scholar exchanges, establishing Confucius Institutes, signing FTAs, increasing high-level diplomatic visits, and engaging directly with regional elites. So far, this economic and political linkage has been effective. For example, some of the staunchest supporters of China's globalized development model are Chilean diplomats that have served in Beijing, like Ambassadors Jorge Heine and Fernando Reyes Matta. This linkage could explain why Chilean agricultural exporters have not further diversified their export markets in the United States and Europe. It will be important to monitor how public perception of China evolves in the coming years, especially if anti-elite and anti-globalization movements in Chile persist.

Now given the upward trend in Chinese investment, the economic and political fallout of the coronavirus pandemic, and the uncertainty as the country rewrites its constitution and prepares 
for a presidential election at the end of 2021, it would behoove the Chileans to reflect on a few questions. First off, if the constitutional convention implements a more left-leaning constitution, what effect will it have on incoming FDI? The uncertainty will likely scare away some investment from the west, however, it is unlikely that the Chinese, and especially Chinese SOEs, will change their behavior. Another important question is what if a misunderstanding like the one between Codelco and Minmetals happened today? The Chinese Embassy may not quietly accept a deal as it did in 2008. And if the Chinese imposed tariffs on Chilean exports like it did to Australia in 2020 for example, what mechanisms does Chile have to respond? Going forward, the Chileans must ensure that deepening economic ties and an increasingly active Chinese foreign policy do not lead to less sovereignty or less agency in negotiations. Finally, more broadly, should Chile continue to view the Chinese only through the lens of economic pragmatism? Or should diplomats, businesspeople, and politicians be more cautious as China becomes more assertive in the global economy?

LAC countries must define their developmental priorities now and implement policies that protect their own interests. If they fail to do so, the trend toward dependency will naturally increase as China's economy continues to grow. However, dependency is not inevitable. Governments still have a tremendous amount of agency when dealing with China and must constantly advocate for themselves during both bilateral and multilateral engagements. In addition, policy makers and businesspeople should constantly seek diversification in their export markets. China certainly presents risks and unknowns, but it undoubtedly presents enormous opportunities as well. In the post-pandemic recovery, those that manage this relationship the best will rebound the quickest.

\section{Bibliographical References}

Álvarez Pelegry, E., \& Larrea Basterra, M. (2018). La energía en Chile: Un banco de pruebas para las estrategias y las transiciones energéticas. Bilbao: Orkestra Instituto Vasco de Competitividad

ASOEX (2021). Quiénes Somos y a Quiénes Representamos. February 2021. Retrieved from: https://www.asoex.cl/quienessomos/la-asociacion/quienessomos.html

Baumgartl, T., Corder, G., Golev, A., Rüttinger, L., Scholl, C., \& van Ackern, P. (2020). KlimRess Impacts of climate change on mining, related environmental risks and raw material supply. Dessau-Roßlau: Umwelt Bundesamt

Cárdenas, L. (2019). Las cifras tras la imparable inversión china en Chile. La Tercera, August 2. Retrieved from: https://www.latercera.com/la-tercera-pm/noticia/las-cifras-tras-laimparable-inversion-china-chile/764938/

Cardoso, F. H., \& Faletto, E. (1979). Dependency and Development in Latin America. Berkeley: University of California Press

Chinese Embassy in Chile (2020). Como país responsable, China siempre concede suma importancia a la protección del ambiente y recursos de la oceanía... [Tweet].October 8. Retrieved from: https://twitter.com/ChinaEmbajada/status/ 1314289426760114177

Codelco (2005). Presidente Ejecutivo explica acuerdo Codelco-Minmetals. June 8. Retrieved from: https://www.codelco.com/presidente-ejecutivo-explica-acuerdo-codelcominmetals/prontus codelco/2011-02-23/122511.html 
Codelco. (2006). Codelco y Minmetals sellaron acuerdo estratégico. February 22. Retrieved from: https://www.codelco.com/codelco-y-minmetals-sellaron-acuerdoestrategico/prontus_codelco/2011-02-22/195525.html

Cominetti, M., Tapia, M., \& Moreno, V. (2010). Grupo chino concreta su primera inversión vitivinícola en Chile. La Tercera, September 4. Retrieved from https://www.latercera.com/noticia/grupo-chino-concreta-su-primera-inversion-vitivinicolaen-chile/

De la Jara, A. (2018). China's Southern Power buys stake in Chile's Transelec. Reuters. March 15. Retrieved from: https://www.reuters.com/article/chile-energy-china-idUSL1N1QX15X

Ellis, R. E. (2009). China in Latin America: The Whats and Wherefores. Boulder and London: Lynne Rienner Publishers

Ellis, R. E. (2011). China-Latin America Military Engagement: Good Will, Good Business, and Strategic Position. Carlisle: Strategic Studies Institute

Ellis, R. E. (2020). Do Latin American Waters Continue to Fall Prey to China's Fishing? Center for Strategic and International Studies, October 23. Retrieved from: https://www.csis.org/analysis/do-latin-american-waters-continue-fall-prey-chinas-fishing

Ellis, R. E. (2020). Mercantilism With Chinese Characteristics in Latin America. NewsMax. December 4. Retrieved from: https://www.newsmax.com/evanellis/mercantilism-LatinAmerica/2020/12/04/id/1000019/

Errázuriz Guilisasti, O. (2006). Las relaciones de Chile y China; del simbolismo a la acción. Estudios internacionales, 39(154), julio-septiembre, pp. 169-179

Fermandois, J. (2005). Mundo y Fin de Mundo. Santiago: Universidad Católica de Chile

Flannery, R. (2018). Look Out, Bordeaux: Fruity Flavor Helps Chile Gain In China's Growing Wine Market. Forbes, March 20. Retrieved from: https://www.forbes.com/sites/russellflannery/2018/03/20/look-out-bordeaux-fruity-flavorhelps-chile-gain-in-chinas-growing-wine-market/?sh=581908281f9f

Frohmann, A., \& Wilhelmy, M. (2016). Chile: A Bridge to Asia? In G. Paz, \& R. Roett. Latin America and the Asian Giants (pp. 227-250). Washington: The Brookings Institute Press

Gachúz, J. C. (2012). Chile's Economic and Political Relationship with China. Journal of Current Chinese Affairs, Vol 41, No 1, pp. 133-154

González, A. (2018). Latin America - China Trade and Investment Amid Global Tensions: A Need to Upgrade and Diversify. Washington: The Atlantic Council

Guzmán, L. (2021). State Grid grows presence in Chile with CGE purchase. Diálogo Chino, February 1. Retrieved from: https://dialogochino.net/en/uncategorised/39680-state-grid-growspresence-in-chile-with-cge-purchase/

Heine, J. (2006). China, Chile and free trade agreements. Estudios Internacionales, 38(152), pp. $143-$ 147

InvestChile (2019). Report on Situation of Foreign Direct Investment (FDI) in Chile. Santiago: Policy Advocacy Unit - InvestChile

InvestChile. (2021). InvestChile portfolio of projects grows by $23 \%$ in 2020 to over US\$21,000 million. January 21. Retrieved from: https://investchile.gob.cl/investchile-portfolio-ofprojects-grows-by-23-in-2020-to-over-us21000-million/

Iturrieta, F., \& Sherwood, D. (2018). China suspects others lobbied to block it from Chilean lithium: official. Reuters, May 8. Retrieved from: https://www.reuters.com/article/us-chile-lithiumchina/china-suspects-others-lobbied-to-block-it-from-chilean-lithium-officialidUSKBN1I93C7 
Jenkins, R. (2019). How China is Reshaping the Global Economy: Development Impacts in Africa and Latin America. New York: Oxford University Press

Jing, Z. (2020). Produce Report. China's Fruit Import and Export Statistics for 2019 Released, February 23. Retrieved from : https://www.producereport.com/article/chinas-fruit-importexport-statistics-2019-released

Kelly, D. (2017). The Recipe for Chile's Fruit Exporting Success. Produce Report, February 21. Retrieved from: https://www.producereport.com/article/recipe-chiles-fruit-exporting-success

Keohane, R. O., \& Nye, J. S. (2012). Power and Interdependence, 4th Edition. London: Pearson Longman

Krugman, P. (2009). Macroeconomic effects of Chinese mercantilism. The New York Times. December 31. Retrieved from: https://krugman.blogs.nytimes.com/2009/12/31/ macroeconomic-effects-of-chinese-mercantilism/

Méndez Morán, D. (2018). 136: el plan de China en América Latina. San Bernadino

MINING.com (2021, January 29). Tianqi's top shareholder to get up to $\$ 2.5 b n$ injection. Retrieved from: https://www.mining.com/tianqis-top-shareholder-to-get-up-to-2-5bn-injection/

Montalva, J. D. \& Navia, P. (2006). Chile and China: Building Relations Beyond Trade? Miami: Center for Hemishperic Policy, University of Miami

Nogales Toledo, D. (2019). La china State Grid se impone a Enel y se queda con Chilquinta en el mayor negocio del año en Chile. La Tercera, Octubre 14. Retrieved from: https://www.latercera.com/pulso/noticia/la-china-state-grid-se-impone-a-enel-y-se-quedacon-chilquinta-en-el-mayor-negocio-del-ano-en-chile/859835/

Olave, R. (2020). Las razones que explican el "reinado" de la cereza chilena en China. La Tercera, February 10. Retrieved from: https://www.latercera.com/conexion-china/noticia/cerezachilena-china/1005102/

Osorio, V. (2018). Embajador de China critica a Bitran por querer bloquear ofertas en SQM: "Puede dejar influencias negativas". El Mercurio Online, April 23. Retrieved from: https://www.emol.com/noticias/Economia/2018/04/23/903560/Embajador-de-China-acusaque-peticion-de-Bitran-para-bloquear-ofertas-de-la-potencia-asiatica-en-SQM-puede-dejarinfluencias-negativas-en-las-relaciones-comerciales.html

Pérez-Cueto, C., \& Novoa, S. (2014). Las lecciones que dejaron las ventas a futuro en Codelco. La Tercera, January 21. Retrieved from: https://www.latercera.com/noticia/las-lecciones-quedejaron-las-ventas-a-futuro-en-codelcol

Pizarro, C., \& Villagrán, J. M. (2020). Inversión china alista 17 nuevos proyectos en Chile. La Tercera, November 28. Retrieved from: https://www.latercera.com/pulso/noticia/inversion-chinaalista-17-nuevos-proyectos-en-chile/2I7DRM6AIZANPEC3SAEUQ3G5NA/

PRC Ministry of Commerce. (2019). The Protocol Upgrading China-Chile Free Trade Agreement Comes into Force Today. China FTA Network, March 1. Retrieved from: http://fta.mofcom.gov.cn/enarticle/enchile/enchilenews/201903/39927_1.html

Produce Report. (2016). Chile Closes In as Top Exporter of Fresh Fruit to China. November 25. Retrieved from: https://www.producereport.com/article/chile-closes-top-exporter-fresh-fruitchina

Produce Report. (2020). [Press Release] Chile Signs Historic Memorandum of Understanding With China. July 20. Retrieved from: https://www.producereport.com/article/press-release-chilesigns-historic-memorandum-understanding-china

Produce Report. (2021). China Approved 10 Fruits for Import in 2020 Amid Slowing Import Growth. January 4. Retrieved from: https://www.producereport.com/article/china-approved-10-fruitsimport-2020-amid-slowing-import-growth 
Reyes Matta, F. (2020). Chile-China: itinerario de 50 años para vencer la distancia. Santiago: La Universidad Andrés Bello

Russell, C. (2021). China fails to learn from Trump backfire in trade war, is losing against Australia. Reuters, January 27. Retrieved from: https://www.reuters.com/article/us-column-russellcommodities-china-aust-idUSKBN29W0HE

Sánchez, D. (2021). Exportadores de cerezas acusan situación crítica por freno en China. La Tercerra, January 25. Retrieved from: https://www.latercera.com/pulso/noticia/agricultura-dice-queno-ha-recibido-comunicacion-oficial-de-china-por-presuntas-cerezascontaminadas/HJMHYO5OVJCHJB2ZOA7747C7ZM/

Stallings, B. (1992). International Influence on Economic Policy: Debt, Stabilization, and Structural Reform. In S. Haggard \& R. Kaufman. The Politics of Economic Adjustment: International Constraints, Distributive Conflicts and the State (pp. 41-88). Princeton: Princeton University Press

Stallings, B. (2020). Dependency in the Twenty-First Century? The Political Economy of China-Latin America Relations. Cambridge: Cambridge University Press

Start-Up Chile. (2021). About Us. Retrieved from: https://www.startupchile.org/about-us/

Tan, S.-L. (2021, January 28). China's cherry sales suffer 'devastating blow' after reports of coronavirus contamination scare consumers. South China Morning Post, January 28. Retrieved from: https://www.scmp.com/economy/china-economy/article/3119490/chinascherry-sales-suffer-devastating-blow-after-reports

Transelec. (2021). Quiénes somos. Retrieved from: https://www.transelec.cl/quienes-somos/

Vallina-Hernandez, A. M. (2021). Sobre el TLC China-Chile. (D. Liebetreu, Interviewer), February 1

Wilhelmy, M. (2017). Escenarios estratégicos en Asia-Pacífico. In R. Allard Neumann, \& W. v. (editores), América Latina y Chile en el mundo global (pp. 169-185). Valparaíso: Salesianos S.A.

Wise, C. (2012). Tratados de libre comercio al estilo chino: los TLC Chile-China y Perú-China. Centro de Investigación de la Universidad del Pacífico, Vol. XXXIX, Nº 71, pp. 161-188

Wise, C. (2017). After the China Boom: What Now for Latin America's Emerging Economies? In M. Myers, \& C. Wise. The Political Economy of China-Latin America Relations in the New Millennium (pp. 143-169). New York: Routledge

Wise, C. (2020). Dragonomics: How Latin America Is Maximizing (or Missing Out on) China's International Development Strategy. New Haven: Yale University Press

Xu, B. (2019). La Emergencia de China. El Mercurio, September 27, Special Edition

Zhu, W. (2020). Un "mapa" de la inversión china en Chile. Diario Financiero, October 2. Retrieved from: https://www.df.cl/noticias/opinion/columnistas/df-conexion-a-china-un-mapa-de-lainversion-china-en-chile/2020-10-01/192505.html 